Agro-Science Journal of Tropical Agriculture, Food, Environment and Extension Volume 11 Number 2 May 2012 pp $62-68$

ISSN TIIY=7455

\title{
GENDER AND RELATIVE ECONOMIC EFFICIENCY IN IMPROVED CASSAVA FARMS OF ABIA STATE, NIGERIA. A STOCHASTIC COST FRONTIER APPROACH.
}

\author{
Ume, S.I, Okoroafor, I.B., Nwaneri, T.C. and Onuh, N.C. \\ Federal College of Agriculture Ishiagu, Ivo L.G.A. Ebonyi State.
}

\begin{abstract}
Multi-stage random sampling technique was used to select 120 improved cassava farmers (60 males and 60 females). Stochastic frontier cost function was used to estimate the level of economic efficiency and its' determinants across gender, while descriptive statistics such as percentage response was used to capture farmers' socioeconomic characteristics, gender participation and constraints to improved cassava production in Abia State. The results showed that the mean economic efficiency of the female group (0.78) was higher than that of male group (0.75). The cost of production of improved cassava to both gender farmer groups were affected by price of fertilizer, price of cassava cutting, land rent and output. Educational level and extension contact were positive and significant at 5\% for both gender farmer groups. Credit was negative but significant at 5\% amongst female farmer groups. Gender participation in improved new cassava showed that those energy sapping operations were dominated by male folk while light operation farming activities such as weeding and fertilizer application was mostly done by women and children. Both gender farmer groups encountered problems of low access to credit, high cost of labour and high cost of planting material. The study calls for policies that will improve both farmer groups access: to credits, extension contact and education. Moreso, new entrant and experienced cassava farmer groups should be encouraged through making available subsidized planting materials and capital inputs.
\end{abstract}

Key word: Stochastic frontier, gender, improved cassava economic efficiency.

\section{INTRODUCTION}

The right to food is fundamental human right which has dominated debates in conferences and world summit. Yet the problem of food insecurity remains unresolved (Uchechi and Okewole, 2010). The global food insecurity is tackled by the two genders. Gender according to Audu, et al (2010) can be used to describe roles, activities, needs and problems of men and women in agricultural production processes. The essence of understanding gender roles in agricultural production is basically to ensure efficient allocation of scarce resources among competing enterprise in the household (Nwaobiala and Isiocha, 2010).

Cassava (Manihot spp) is the major sources of carbohydrate food for people in the low land regions of tropical Africa (Ezedimma, 2006). Apart from its dietary relevance, there are other diverse uses of cassava: pharmaceutical, soft drinks confectionary and livestock feed (Ezedinma, 2006). FAO (2006) reported that Nigeria is the largest producer of cassava in the world with total output of 34 million metric tons per annum.

Cassava is endeared to small holder cassava farmers by possession of the following attributes could be processed into different forms for man's use, the ease by which the product can be prepared and served, low price relative to other energy giving-food (Okereke and Ojewole, 2005) thrives in marginal soils and erratic rainfall than any other root and tuber, ease of 
propagation and can be stored underground and harvested in piece meal (FAO, 2006).

Furthermore, the foreign exchange potentials and $10 \%$ cassava flour inclusion in bread production as directed by Nigerian government propelled increase in cassava cropping area (CBN, 2003). The development and introduction of improved new varieties of cassava by National Root Crops Research Institute (NRCRI) and International Institute for Tropical Agriculture (IITA) including NR 8082, 8083 and IITA 0580 helped immensely to boost farmers' cassava yield (NKematu, 2005). Several studies, (Ezedinma, 2006, NRCRI, 2006 and Nwakor et al, 2010) opined that these improved cassava varieties have the potentials of pushing further cassava production frontier through possession of attributes including, high yield of 35-45 metric tons/ha, starch content of $12-15 \%$ dry matter content of $30-42 \%$, high flour yield and tolerant to major pests and disease.

However, studies on improved cassava had been carried out in agronomy and breeding (NRCRI, 2006) but information on the economic efficiency is scarce. The objectives of this study were to measure the level of economic efficiency and its' determinants in improved cassava farms in Abia State, Nigeria across gender using the stochastic frontier. More so, the different gender participation in cassava production as well as the farmers' production constraints was also considered. Economic efficiency here is the ability of a farmer to produce a predetermined quantity of output at a minimum cost for a given level of technology.

\section{MATERIALS AND METHODS}

The study was carried out in Abia State. Abia State has land mass of $6,320 \mathrm{~km}^{2}$ and population of $4,22.48$ million people (NPC, 2006). The state lies on latitude $4^{\circ} 40^{\prime}$ and $6^{\circ} 14^{\prime}$ $\mathrm{N}$ of the equator and longitude $7^{\circ} 10^{\prime}$ and $8^{\circ} 12^{\prime} \mathrm{E}$ of Greenwich meridian. The state is bounded in the North by Ebonyi State, in the south by Rivers state, in the east by Cross River state, in the west by Imo State and Anambra State.

Abia State has 17 local government areas with three agricultural zones; Aba, Ohafia and Umuahia. Structured questionnaire and oral interviewed were used to collect information on socioeconomic characteristics of the farmers, such as age, level of education, farming experience, prices of inputs and outputs. Multi stage sampling technique was used to select 120 farmers (60 males and 60 females).
Two zones were selected out of three agricultural zone: Umuahia and Ohafia zones. Two local government areas were selected from each of the two zones, Umuahia North and Ikwuano L.G.A. from Umuahia zone, and Bende and Umunneochi from Ohafia zone. This gave a total of four local government areas. Five communities were selected from each local government area. Finally, six farmers were randomly selected from the twenty communities. This brought to total of one hundred and twenty farmers (sixty males and sixty females).

Descriptive statistics such as percentage, frequencies and mean count were used to capture the farmers socioeconomic characterises, gender participation in cassava production activities and gender constraint. The efficiency of cassava farmers was estimated using Cobb Douglas cost functional forms analysed on the basis of the stochastic frontier $\operatorname{lnc},=\alpha_{0}+\alpha_{1} \operatorname{Inp}_{1}+\alpha_{2} \operatorname{Inp}_{2}+\alpha_{3} \operatorname{Inp}_{3}+\alpha_{4} \operatorname{Inp}_{4}+$ $\alpha_{5} \operatorname{Inp}_{5}+\alpha_{6} \operatorname{In}_{7}+\mathrm{V}_{1}-\mathrm{U}_{1}$ (1)

In = natural logarithm; $\mathrm{C}_{1}=$ total production cost by the $\mathrm{I}$ - th farmer in naira

$\mathrm{P}_{1}$ wage rate in $(\mathbb{N})$ /Manday; $\mathrm{P}_{2}=$ price of cassava cutting (bundles) ( $) / \mathrm{kg}$;

$\mathrm{P}_{3}=$ price of fertilizer in $(\mathrm{N}) / \mathrm{kg} ; \quad \mathrm{P}_{4}=$ capital $(\mathrm{N})$ measured by depreciation charges on farm tools and equipment interest on borrowed capital, rent on land; $\mathrm{P}_{5}=$ land rent in $(\mathbb{N}) / \mathrm{ha}$; $\mathrm{Y}^{*}=$ output of cassava in $\mathrm{kg} / \mathrm{ha} ; \alpha^{\mathrm{s}}=$ coefficient estimate;

$\mathrm{V}_{1}=$ symmetric error term, which account for random variation in output due to factors beyond the farmer; $\mathrm{U}_{1}=$ Non negative random variable representing inefficiency in production relative to the stochastic frontier.

\section{Determinants of Economic Efficiency}

The maximum likelihood estimation procedure using computer software 4.1 was used to determine factors contributing to the observed economic efficiency in improved cassava production. This is represented thus;

$\mathrm{EE}=\delta_{0}+\delta_{1} \mathrm{M}_{1}+\delta_{2} \mathrm{M}_{2}+\delta_{3} \mathrm{M}_{3}+\delta_{4} \mathrm{M}_{4}+\delta_{5} \mathrm{M}_{5}+$ $\delta_{6} \mathrm{M}_{6}+\delta_{7} \mathrm{M}_{7}+\delta_{8} \mathrm{M}_{8}$;

$\mathrm{EE}=$ Economic efficiency; $\mathrm{M}_{1}=$ Age of the farmers in years; $M_{2}=$ Level of education (in years); $\mathrm{M}_{3}=$ Farm size in hectare; $\mathrm{M}_{4}=$ House hold size (in number)

$\mathrm{M}_{5}=$ Farming experience (in years); $\mathrm{M}_{6}=$ Membership of cooperative Association $($ member $=1$, otherwise 0$) ; \quad \mathbf{M}_{7}=$ Extension Contact (number of visits); $\mathrm{M}_{8}=$ Access to credit $($ access $=1$, other wise, 0$) ; \quad \delta_{0}=$ Intercepts, $\delta_{1}-\delta_{8}=$ parameter estimates. 
Ume, S.I, Okoroafor, I.B., Nwaneri, T.C. and Onuh, N.C.

\section{RESULTS AND DISCUSSIONS}

Table 1 shows that the average age of an improved cassava male farmer was 42 years with household size of 8 person and cultivated 0.42 hectares of land with 42 extension visits. The average male farmer had farming experience of 12 year with 9.2 year of formal education. 54.6 mandays of labour were employed to produce output of $275.8 \mathrm{~kg}$ of cassava roots per annum. A typical female farmer was 38 years old on the average, having formal education 8.75 years with farming experience of 7.32 years and cultivated 0.42 hectares of land. She had 27 number of extension visits and employed 34.12 mandays of labour to produced cassava output of $147.13 \mathrm{~kg}$.

The maximum estimates of the cost frontier function for improved cassava production in Abia State is shown in table 2. The total variance for both male and female was significant at $5 \%$ probability level. This implies goodness of fit and correctness of composite error. The variance ratio for both farmer groups was significant at $5 \%$ probability level. This indicates the variability in the output of the cassava farmer groups that are unexplained by the function which is due to inefficiency.

Table 2, shows that wage rate, price of cassava cutting, price of fertilizer, output and land rent were significant in both farmer groups. This implies that the increase of any of the variables will increase cost of cocoyam production.

\section{Sources of Economic Efficiency}

The coefficient of educational level of both farmer groups had positive relationship to economic efficiency and significant at 5\% probability level. Education helps not only to increase farmers' productivity but also enhances his/her ability to understand and evaluate new production techniques (Iheke, 2010).

Farming experience was positive in farmer groups and significant to economic efficiency at 5\% alpha probability level. This finding is in consonance with Nwaru, (2004), who opined that the number of years spent in any farm business may give an indication of the practical knowledge acquired on how he/she can overcome certain inherent problem associated with that farm business. More so, farming experience helps in resource combination for better and optimal manner. Extension contact was positively related economic efficiency and significant at $5 \%$ probability level for both gender groups.

Table 1: The average statistics of male and female improved cassava farmers.

\begin{tabular}{lllllll}
\hline & Mean value & \multicolumn{3}{c}{ Maximum values } & \multicolumn{2}{c}{ Minimum values } \\
\hline Variable & Male & Female & Male & Female & Male & Female \\
Age (yrs) & 4.2 & 38 & 65 & 72 & 24 & 26 \\
Farm size (ha) & 0.42 & 0.48 & 1. ha & 1.5 ha & 24 & 0.04 \\
Household size(no) & 8 & 6 & 10 & 8 & 4 & 3 \\
Level of education & 9.2 & 7.32 & 19 & 16 & 6 & 0 \\
Farming experience & 12 & 10 & 39 & 36 & 4 & 6 \\
Labour (Monday) & 54.66 & 34.12 & 72.4 & 62.1 & 14 & 12 \\
Extension visit(No) & 42 & 27 & 47 & 36 & 4 & 3 \\
Output (kg) & 275.8 & 147.13 & 385.4 & 2.05 & 98.2 & 24.1 \\
\hline
\end{tabular}

Source: Field Survey, 2011. 
Table 2: Maximum likelihood estimate the Cobb Douglas stochastic production function for improved cassava farmer.

\begin{tabular}{|c|c|c|c|}
\hline Production factor & Parameter & Male & Female \\
\hline Constant & $\alpha_{0}$ & $\begin{array}{l}7.699 \\
(10.304)^{\mathrm{xx}}\end{array}$ & $\begin{array}{l}8.448 \\
(6.333)^{\mathrm{xx}}\end{array}$ \\
\hline Wages & $\alpha_{1}$ & $\begin{array}{l}0.0039 \\
(2.314)^{\text {** }}\end{array}$ & $\begin{array}{l}0.0007 \\
(4.141)^{* \cdot *}\end{array}$ \\
\hline Price of cutting & $\alpha_{2}$ & $\begin{array}{l}0.0544 \\
(1.456)^{* * *}\end{array}$ & $\begin{array}{l}0.676 \\
(2.007)^{\text {** }}\end{array}$ \\
\hline Price of fertilizer & $\alpha_{3}$ & $\begin{array}{l}0.0548 \\
(1.788)^{\text {*** }}\end{array}$ & $\begin{array}{l}0.0474 \\
(2.207)^{* *}\end{array}$ \\
\hline Capital & $\alpha_{4}$ & $\begin{array}{l}0.4197 \\
(-1.375)\end{array}$ & $\begin{array}{l}0.772 \\
(2.724)\end{array}$ \\
\hline Land rent & $\alpha_{5}$ & $\begin{array}{l}-2.342 \\
(4.3391)^{\mathrm{xx}}\end{array}$ & $\begin{array}{l}0.672 \\
(1.114)^{x^{*}}\end{array}$ \\
\hline Output & $\alpha_{6}$ & $\begin{array}{l}0.101 \\
(10.110)^{\mathrm{xx}}\end{array}$ & $\begin{array}{l}1.001 \\
(3.752)^{\mathrm{xx}}\end{array}$ \\
\hline \multicolumn{4}{|l|}{ Efficiency factor } \\
\hline Constant term & $\mathrm{M}_{0}$ & $\begin{array}{l}10.332 \\
(1.578)\end{array}$ & $\begin{array}{l}4.441 \\
(0.975)\end{array}$ \\
\hline Age & $\mathrm{M}_{1}$ & $\begin{array}{l}2.506 \\
(.188)\end{array}$ & $\begin{array}{l}1.997 \\
(.017)\end{array}$ \\
\hline Level of education & $\mathrm{M}_{2}$ & $\begin{array}{l}1.347 \\
(6.411)^{* *}\end{array}$ & $\begin{array}{l}0.367 \\
(5.008)^{* *}\end{array}$ \\
\hline Farm size & $\mathrm{M}_{3}$ & $\begin{array}{l}-.047 \\
(-.287)^{* *}\end{array}$ & $\begin{array}{l}-.059 \\
(-.347)\end{array}$ \\
\hline House hold size & $\mathrm{M}_{4}$ & $\begin{array}{l}2.778 \\
(0.681)\end{array}$ & $\begin{array}{l}.0162 \\
(-2.008)^{* *}\end{array}$ \\
\hline Farming experience & $\mathrm{M}_{5}$ & $\begin{array}{l}0.817 \\
(1.567)^{\text {** }}\end{array}$ & $\begin{array}{l}0.662 \\
(-.305)^{\text {*** }}\end{array}$ \\
\hline Membership organ & $\mathrm{M}_{6}$ & $\begin{array}{l}0.0387 \\
(1.224)\end{array}$ & $\begin{array}{l}-0.004 \\
(-5.027)\end{array}$ \\
\hline Extension contact & $\mathrm{M}_{7}$ & $\begin{array}{l}0.721 \\
(3.164)^{* *}\end{array}$ & $\begin{array}{l}1.084 \\
(2.00)^{* *}\end{array}$ \\
\hline Access to credit & $\mathrm{M}_{8}$ & $\begin{array}{l}2.990 \\
(0.720)\end{array}$ & $\begin{array}{l}0.113 \\
(-1.23)^{* *}\end{array}$ \\
\hline \multicolumn{4}{|l|}{ Diagnostic Statistics } \\
\hline Total variance & & $\begin{array}{l}0.720 \\
(0.129)^{\text {** }}\end{array}$ & $\begin{array}{l}0.324 \\
(0.118)^{* *}\end{array}$ \\
\hline Variance ratio & & $\begin{array}{l}1.788 \\
(0.299)\end{array}$ & $\begin{array}{l}3.007 \\
(-1.772)\end{array}$ \\
\hline LR Test & & $\begin{array}{l}6.007 \\
(2.990)^{x x}\end{array}$ & $\begin{array}{l}7.091 \\
(1.098)^{\mathrm{xx}}\end{array}$ \\
\hline Long likelihood fn & & 5.265 & 7.989 \\
\hline
\end{tabular}

Source: Field Survey Data 2011.

Note $\mathrm{xx}$ is significant at $5 \%$. Value in parenthesis $=\mathrm{t}$-value.

Extension is a conduit for dissemination of agricultural technology to the farmers (Ume, et al 2009).

Credit coefficient was negative but statistically significant at $5 \%$ of probability level in the female farmer group. Credit is needed to procure production inputs and for payment of labour (Eze and Akpa, 2010). Several studies (Ume and Okoye, 2009, Okoye and Onyenweaku, 2008; Eze and Akpa, 2010) confirm this finding, as many of the farmers divert this important resource to non agricultural uses.

Table 3 shows the distribution, of economic efficiency of improved cassava production. The economic efficiency indices connote precisely the levels of farmers' ability $t$ produce predetermined output at minimal cost. The male farmers group had economic efficiency indices ranged between $24 \%$ and $98 \%$ for minimum and maximum economic efficiencies, respectively with mean economic efficiency of $75 \%$. The female economic efficiency ranged from $26 \%$ to $99 \%$ with mean of $78 \%$. More so, the table showed that $11 \%$ of male and $9.3 \%$ of female farmers had economic efficiency indices of $80 \%$ and above. In the short run, there are opportunities for increasing improved cassava production by $25 \%$ and $22 \%$ by male and female farmer groups respectively, by adopting the techniques and technologies employed by the best practice in improved cassava farms. The result of the mean economic efficiency showed that most farmer groups operated near the frontier. The level of economic efficiency obtain in this study suggest that opportunities exist for increasing productivity and income through increased efficiency in resource utilization by cassava crop farmer groups in the State. 
Table 3; Distribution of Gender According to Economic Efficiency indices

\begin{tabular}{|c|c|c|c|c|}
\hline \multirow[b]{2}{*}{ Indices } & \multicolumn{2}{|c|}{ Male } & \multicolumn{2}{|c|}{ Female } \\
\hline & Frequency & Percentage & Frequency & Percentage \\
\hline $0.20-0.29$ & $2 \times$ & 3.3 & 3 & 5 \\
\hline $0.30-0.39$ & 8 & 13.3 & 7 & 11.7 \\
\hline $0.40-0.49$ & 7 & 11.7 & 8 & 13.3 \\
\hline $0.50-0.59$ & 11 & 18.3 & 12 & 20 \\
\hline $0.60-0.69$ & 10 & 16.7 & 6 & 10 \\
\hline $0.70-0.79$ & 12 & 20 & 7 & 11.7 \\
\hline $0.80-0.89$ & 6 & 10 & 10 & 16.7 \\
\hline $0.90-0.99$ & 5 & 8.3 & 7 & 11.7 \\
\hline Total & 60 & 100 & 60 & 100 \\
\hline
\end{tabular}

Source Field Survey, 2011.

Maximum economic efficiency $=0.98: 0.99$, minimum economic efficiency $=0.24: 0.26$, mean economic efficiency $=0.75: 0.78$

Table 4: Distribution of the Respondents based on Gender Participation in Cassava Production

\begin{tabular}{|c|c|c|c|c|}
\hline \multirow[t]{3}{*}{ Farming Activities } & \multicolumn{4}{|c|}{ Gender } \\
\hline & \multicolumn{2}{|c|}{ Male } & \multicolumn{2}{|c|}{ Female } \\
\hline & Frequency & Percentage & Frequency & Percentage \\
\hline Land clearing Male & 90 & 75 & 30 & 25 \\
\hline Planting Female & 90 & 75 & 30 & 25 \\
\hline Weeding Female & 120 & 100 & - & - \\
\hline Fertilizer application Female & 95 & 79.2 & 25 & 20.8 \\
\hline Spraying of herbicides Male & 87 & 72.6 & 33 & 27.4 \\
\hline Harvesting Male & 69 & 57.5 & 51 & 42.5 \\
\hline
\end{tabular}

Source: Field Survey, 2011

Table 4 shows the distribution of the respondents based on gender participation in cassava production activities. Out of the 8 cassava production activities studied, 5 representing $62.5 \%$ were dominated by male, while 3 others, $35 \%$ were dominated by female. The cassava farming activities dominated by male were land clearing (75\%), land preparation $(83 \%)$, spraying of herbicides $(72.6 \%)$ and spraying of pesticides $(83.3 \%)$. The cassava farming activation dominated by women were planting (90), weeding (100\%) and fertilizer application (79.2). Land preparation, task is often male specific and very tedious and requires energetic and able-bodied individuals which is commonly found in male. Several studies (Audu et al 2010), Ume et al 2009; Ezedinma, 2004) conformed to this finding.
On the domination of male in spraying of chemical (herbicide, $83.3 \%$ and pesticides, $72.6 \%$ ), Audu et al (2010) opined that male is often financially advantaged and has more access to information on the use of farm inputs than female counterpart. The women dominated farming activities included: weeding, fertilizer application and harvesting which require less energy and light implement such as hoe and cutlass. This finding agrees with Ezedinma (2004) who reported same on use of labour in cassava production. 
Table 5: Distribution of Gender Respondents According to Production Constraints

\begin{tabular}{|c|c|c|c|c|}
\hline \multirow[t]{2}{*}{ Variable } & \multicolumn{2}{|c|}{ Male } & \multicolumn{2}{|c|}{ Female } \\
\hline & Percentage & Ranking & Percentage & Ranking \\
\hline High labour cost & 96.8 & 2 & 98 & 2 \\
\hline high cost of planting material & 90 & 4 & 92 & 3 \\
\hline Poor feeder road & 76 & 7 & 85.7 & 8 \\
\hline Poor access to credit & 100 & 1 & 100 & 1 \\
\hline Inadequate extension contact & 75 & 8 & 87 & 6 \\
\hline Poor soil fertility & 80 & 5 & 86.8 & 7 \\
\hline Land problem & 78 & 6 & 95.6 & 4 \\
\hline $\begin{array}{l}\text { Low } \\
\text { ce of product }\end{array}$ & 95 & 3 & 95.4 & 5 \\
\hline High cost of agro chemical & 67 & 10 & 75 & 9 \\
\hline Poor knowledge of cassava processing technology & 32 & 12 & 74 & 10 \\
\hline Theft & 61 & 11 & 66 & 12 \\
\hline Cattle rearers & 68 & 9 & 68 & 11 \\
\hline
\end{tabular}

Source: Field Survey, 2011.

Table 5 shows the constraints to improved cassava production among gender groups in Abia State. The result revealed that male farmers encountered the following: poor access to credit $(100 \%)$, high cost of labour $(98 \%)$, low price of product $(95 \%)$, high cost of planting material $(90 \%)$, poor soil fertility $(80 \%)$ and poor feeder road $(76 \%)$.

The female farmers experienced poor access to credit (100\%), high labour cost $(98 \%)$, high cost of planting material (92\%), limited land (95.4\%), inadequate access to extension (87\%). Majority (100\%) of both gender farmer groups faced the problem of poor access to credit. This assertion is in consonance with Ume et al (2009) who linked this trend to high interest rate and collateral that are often demanded by lending agencies. However, $96.8 \%$ and $98 \%$ of the male and female farmer groups respectively encountered high labour cost. Dimelu et al. (2007) confirms to this finding. They reported that with the increase in population, rural urban migration, the ageing of the rural population and the feminization of agriculture, rural farm labour is much likely to remain inelastic and expensive.

\section{CONCLUSION AND RECOMMENDATIONS}

The result of the study shows that the economic efficiency for improved cassava production in Abia State is relatively high for both gender groups. The individual technical efficiency level for the male farmers range between $26 \%$ and $99 \%$ with mean of $75 \%$ while that of female farmer group ranged between $26 \%$ and $99 \%$ with mean of $78 \%$. This implied that significant opportunities still exist in increasing productivity and income of improved cassava farmers in the state. Determinants of economic efficiency for both gender farmer groups were level of education, farming experience and extension visit. The important constraints encountered by both gender farmer groups include - low access to credit, high labour cost and inadequate extension contact.

Therefore, policies aimed at improving farmers' access to education, extension visits, and credits will enhance economic efficiency in improved cassava production in the state.

\section{REFERENCES}

Audu, S.I. Ukwuteno, S.O. and Saliu, O.J. (2010) Gender roles in agricultural production in Ankpa local government area, Kogi State Nigeria. The Nigeria agricultural journal: 41(2) 46-50.

CBN, (2003) Central bank of Nigeria annual report and statement of account for the year $31^{\text {st }}$ December 2004 pp. 142-145.

Dimelu, M.U, Okoye, A.C, Okoye B.C, Agwu, A.E and Aniedu, O.C (2007) Determination of gender efficiency of small-holder cocoyam farmers in Nsukka agricultural zone of Enugu State, Nigeria. Academic Journal 4(1):28-32.

Eze, C.I and Akpa, C.E (2010) Analysis of Technical efficiency of National Fadama 11 facility on arable crop farmers in Imo State, Nigeria. Nigeria agricultural journal 41(1):109-114.

Ezedinma, C (2006). Cross border trade in cassavabased products in Dawanau Market, Kano Nigeria. In Ezedinma C. Sanni L and Okechukwu R. (ed) socioeconomic studies of selected cassava markets in Nigeria. International Institute of Tropical Agriculture Nigeria. 55pp. 
FAO, (2006). The state of food security in the world, $4^{\text {th }} \quad$ edition, available from http://www.centreonhunger.org.

Iheke, S.O (2010): Market access, income diversification and welfare status of rural farm household in Abia State, Nigeria. The Nigeria agricultural journal (41 (2): 13-17

Nkematu. J.C. (2005). Anambra State agricultural development project extension services. Report for 2005. In proceeding of the $14^{\text {th }}$ annual farming system research and extension workshop in south eastern of Nigeria. Pp 100105

NPC (2006) National Population Commission estimated population figures. Abuja National Population Commission of Nigeria.

NRCRI (2006) Annual Report National Root Crop Research Institute, Umudike, Umuahia.

Nwakor, F.N, Ifenkwe, G.E and Ekereke (2010). Determinates of the adoption of improved cassava varieties (TME, 419 and NR 8082) among farmers in Abia State. The Nigeria Agricultural Journal, 41 (1). 93-100.

Nwaobiala, C. U. and Isiocha, S. (2010) An Overview of Gender Issues in Nigeria Agriculture. Proceeding of $43^{\text {rd }}$ Annual Conference of the Agricultural Society of Nigeria Ladoke Adeoke University of Technology Ogbomosho, Oyo state pp 460-464

Nwaru, J.C.(2004): Rural credit market and arable crop production in Imo State, Nigeria. Ph.D
Dissertation Department of Agricultural Economics. Michael Okpara University of Agriculture, Umuahia.

Okereke, C. and Ojewola, A.S (2005). Utilization of cassava, sweet potato and cocoyam meal as dietary energy in Surulere L.G.A. Oyo State Proceedings of $39^{\text {th }}$ Annual Conference of Agricultural Society of Nigeria. Benin 2005. pp:26-28.

Okoye, B.C. and Onyenweaku, C.E. (2007): Economic efficiency of small holder cocoyam farmers in Anamabra State, Nigeria: A Trans-log stochastic frontier cost function approach. Mendwell Journals; 4:535-546.

Uchechi A and Okewole, J.A. (2010) food insecurity among rural dwellers in Nigeria. A case study of Abia state. Proceedings of agricultural society of Nigeria, Lodokeke Adegoke university of science and technology, Ogbomos Oyo.

Ume, S. I. and Okoye, F. U. (2009). Child labour in rice production. A case study of Anambra Agricultural Zone of Anambra State, Nigeria. Journal of Arts and Social Science Education, 1(1):233-239.

Ume, S.I. Ucoh, E.V and Okoronkwo M.O. (2009). Adoption of improved rice production technology by farmers in Anambra State. 3(1):1-6. 